\title{
Obituary: John H. D'Arms (1934-2002)
}

The untimely death of John D'Arms on January 22, 2002 deprived American higher education of one its strongest and most influential advocates for the humanities, the community of classical scholars of a widely respected ancient historian, and Roman studies of a leading figure, whose pioneering work during the 1970s and 1980s on villa culture, Italian municipal life, the commercial activities of the Roman élite, and Roman foodways demonstrated irrefutably the relevance of the social and economic behavior and attitudes of the ancient Romans for the cultural history of Roman Italy and for the political history of Rome, especially during the central period of the late Republic and early Empire.

Following education at Princeton and Oxford, in 1965 John received his Ph.D. degree in Classical Philology from Harvard, where he worked closely under the supervision of $\mathrm{H}$. Bloch. By that time John had already established a deep love of Italy, his second patria, and a pattern of academic service to American institutions aiming to promote the study of Roman antiquity through a first-hand familiarity with the Italian landscape and the topography, epigraphy, and archaeology of Roman Italy. Beginning even before he earned the Ph.D., he served virtually all of the major American academic classical programs in Italy, including the Vergilian Society Classical Summer School at Cuma, the Intercollegiate Center for Classical Studies in Rome (1967-68), and the American Academy in Rome, as Professor-in-Charge of the Summer School (1971-73) and, ultimately (and simultaneously), as Director and Andrew W. Mellon Professor (1977-80) - an unparalleled onus and honor, aptly characterized elsewhere as "a potentially crushing dual responsibility, carried off with apparent effortlessness". ${ }^{1}$ Despite his frequent and extended sojourns in Italy, he rose rapidly from the rank of Assistant Professor to Professor of Classical Studies at the University of Michigan (1965-72). As that department's Chairman, a position he held almost continuously from 1972 to 1985, he greatly furthered the links at Michigan among the graduate programs in classical studies, archaeology, and ancient history.

The second half of $D^{\prime}$ Arms's professional career was distinguished by a prestigious series of posts in academic administration, as Dean of the Graduate School and Vice Provost for Academic Affairs at Michigan (for which he was awarded a medal for outstanding service), and ultimately as President of the American Council of Learned Societies, a position he held until his death. Among other honors, he was appointed by President Clinton to the governing body of the National Endowment for the Humanities.

In scholarship, a half-dozen short articles on particular passages of Vergil, Cicero, and Horace preceded the publication in 1970 of a revised version of his doctoral dissertation, Romans on the Bay of Naples: a social and cultural study of the villas and their owners from 150 B.C. to A.D. 400 (Harvard University Press). This work, which included a catalogue of all known villa-owners of Roman Campania, was remarkable for its precocious synthesis of prosopographical expertise and up-to-date command of archaeological sources. It has never been superseded. (Too long out of print, the book is now being re-issued, along with several of his major articles and a comprehensive bibliography, in a volume in tribute edited by two of his Italian friends, E. Lo Cascio and F. Zevi, in the series Pragmateiai.) The Anglophone world was thinly represented but very well served during the 1960s and early 1970s by two young men who could be seen traipsing around the Campanian countryside or poking into the magazzini of the Naples Museum, voraciously acquiring the firsthand knowledge of Roman antiquity so essential for an understanding of the region. A generation or two of their disciples still populates the ground, but the likes of M. Frederiksen and D'Arms are not likely to be seen again. Friends of both remark their shared qualities of wide learning lightly carried and an enviable geniality capable of embracing all from the most senior to the most junior scholar; certainly John had the remarkable ability (and rare propensity) to approach the youngest student, to inquire amiably about his or her work, and to share unobtrusively his own learning and insight.

These two scholars shared a special interest in Puteoli. Frederiksen's authoritative entry in $R E$ appeared in 1959. John followed with 5 articles on the town, mainly based on epigraphic evidence (1972-75; others would appear later). His "Puteoli in the second century of the Roman Empire: a social and economic study," JRS 64 (1974), complementing Frederiksen's entry in RE, remains the standard treatment and continues to be cited as a model discussion of the interplay of social and economic factors in the changing fortunes of a Roman town. His "Eighteen unedited inscriptions from Puteoli," AJA 77 (1973), performed the signal service of making available some of the epigraphic riches housed in North American university collections, in this case some of the 300 Latin inscriptions from the collection purchased from G. De Criscio, the parish priest of Pozzuoli, during the early years of the 20th c. and now in the Kelsey Museum at the University of Michigan.

From Puteoli, D'Arms's scholarly attention turned naturally to maritime commerce. He recognized early the importance of, and responded judiciously to, the gauntlet thrown down by M. I. Finley in The ancient 
economy (Berkeley 1973). An early indication of his appreciation of the implications of the broader theoretical issues raised by Finley (as well as a prosopographer's natural delight in the vagaries of onomastic conventions) can be seen in his "M. I. Rostovtzeff and M. I. Finley: the status of traders in the Roman world" (1977). There followed a trio of articles in Italian concerned with the economic significance of ville rustiche in the Italian economy - note especially his magisterial study "Rapporti socio-economici fra città e territorio nella prima età imperiale," Antichità Altoadriatiche 15 (1979) - and a significant precursor to a larger study "Senators' involvement in commerce in the late Republic: some Ciceronian evidence", in his co-edited Roman seaborne commerce: studies in archaeology and history (American Academy in Rome, 1980).

A year later the full study, Commerce and social standing in ancient Rome, was published by Harvard. In a series of closely argued case-studies covering such diverse territory as the notorious Sestius amphorae, the Augustales of Puteoli and Ostia, and "the typicality of Trimalchio" (a literary as well as an historical essay that should be required reading for any student of the Roman novel), he demolished the widely held view that members of Rome's ruling élite refrained from commercial enterprise on the grounds that trade was considered sordid and unnecessary for maintaining the senatorial fortunes on which their status depended. The workings of large-scale Roman commerce were shown to be multifarious and complex, involving direct and indirect, dependent and independent, agents and operatives; business enterprises, in other words, were pursued through a far more sophisticated system of networks than Finley's minimalist model seemed to allow.

From business to pleasure: dining and drinking in the Roman world, and the social conventions that governed them, formed his scholarly focus for the last two decades. Typically, he embarked upon the topic in advance of the wave of enthusiasm for ancient foodways that now permeates cultural studies of the GrecoRoman world. Regrettably, notes for the manuscript of a monograph, tentatively entitled Food and drink in Roman society, do not seem far enough advanced to be worked up for publication. Fortunately, we have 7 articles (1984-2000, the most recent being in JRA 13) to provide a foretaste of the rich meal he would have served. It may be fair to say that he was particularly interested in questions of hierarchy and status and in the ideology of equality that typified the Roman convivium. Conference papers, and the convivial occasions that accompany them, provided an appropriate medium for the original dissemination of this work, and it was always the-last of his three main areas of concern - the ideology of equality - that characterized his own participation. He enjoyed nothing so much as good conversation over good food and drink, about scholarship, certainly, but also about family, friends, and the nature of the good life (his friend D. O. Ross read passages to this effect, from Horace's Satires, 2.6.67-76 and 1.5.44, at D'Arms's memorial service).

Fortunately, a major work of synthesis was not entirely lacking from his later career. "The social and economic history of Italy" in F. Vittinghoff (ed.), Europäische Wirtschafts und Sozialgeschichte in der römischen Kaiserzeit (1990), is the best 50-page survey of the topic one will find. But the younger generation new to his work will perhaps find the most rewarding introduction to his scholarship in his last major article. Presenting new inscriptions involving important evidence for municipal euergetism, the social position of Augustales and the economic ramifications of their bid for status, and the topography of one of the jewels of crater ille delicatus, his "Memory, money, and status at Misenum," JRS 90 (2000), provides an exemplary model of erudition harnessed in the service of historical interpretation. That these remarkable documents were entrusted for publication to an American scholar writing in English is but one sign of the high esteem in which his Italian colleagues held him.

But the trenchant urbanity of his writing cannot convey the lively enthusiasm he brought to the classroom. He considered teaching a major art, and devoted to it the care and skill of a master craftsman. He always felt that the future of classical studies (and, indeed, of the humanities) lay with the young, and a class well taught was for him an occasion for pride. When, a few days before he died, he last closed the door on his office at Columbia University, he left open on his desk, half read and characteristically annotated, the first book of a young scholar (Matthew Roller's Controlling autocracy) which he was clearly intent on absorbing, whether for his own research or for an upcoming seminar on Latin epigraphy we can never know.

Those who knew John only in later life, clad in a dark business suit as a high-level academic administrator, no doubt remarked the lively step and the twinkle in the eye. But those who have known him longer will prefer to remember him in more casual attire, playing the piano in a Dixieland Jazz Band, or traversing the streets of Rome or the varied landscape of the Campanian campagna (beloved loci amoeni) pitched slightly forward, as if he had some interesting or amusing bit of wisdom to impart (as he usually did). We will long in vain for that next encounter and can only address his shade with the conventional salutation, inadequate but just: sit tibi terra levis. 